\title{
Biological Characterization of White Line-Inducing Principle (WLIP) Produced by Pseudomonas reactans NCPPB1311
}

\author{
Pietro Lo Cantore, ${ }^{1}$ Silvia Lazzaroni, ${ }^{2}$ Manuela Coraiola, ${ }^{3}$ Mauro Dalla Serra, ${ }^{3}$ Claudia Cafarchia, ${ }^{4}$ \\ Antonio Evidente, ${ }^{2}$ and Nicola S. lacobellis ${ }^{1}$ \\ 1Dipartimento di Biologia, Difesa e Biotecnologie Agro Forestali, Università degli Studi della Basilicata, Viale dell'Ateneo \\ Lucano 10, 85100 Potenza, Italy; ${ }^{2}$ Dipartimento di Scienze del Suolo, della Pianta e dell'Ambiente, Università di Napoli \\ "Federico II", Portici (Napoli), Italy; ${ }^{3}$ CNR-ITC Istituto di Biofisica-Sezione di Trento, Povo (Trento); ${ }^{4}$ Dipartimento di \\ Sanità e Benessere Animale, Università di Bari, Italy
}

Submitted 21 December 2005. Accepted 8 June 2006.

The biological activities of the lipodepsipeptides (LDP) white line-inducing principle (WLIP), produced by Pseudomonas reactans NCPPB1311, and tolaasin I, produced by $P$. tolaasii NCPPB2192, were compared. Antimicrobial assays showed that both LDP inhibited the growth of fungi-including the cultivated mushrooms Agaricus bisporus, Lentinus edodes, and Pleurotus spp.- chromista, and gram-positive bacteria. Assays of the two LDP on blocks of Agaricus bisporus showed their capacity to alter the mushrooms' pseudo-tissues though WLIP was less active than that of tolaasin I. Contrary to previous studies, tolaasin I was found to inhibit the growth of gram-negative bacteria belonging to the genera Escherichia, Erwinia, Agrobacterium, Pseudomonas, and Xanthomonas. The only gram-negative bacterium affected by WLIP was Erwinia carotovora subsp. carotovora. Both WLIP and tolaasin I caused red blood cell lysis through a colloid-osmotic shock mediated by transmembrane pores; however, the haemolytic activity of WLIP was greater than that of tolaasin I. Transmembrane pores, at a concentration corresponding to $1.5 \times \mathrm{C}_{50}$, showed a radius between 1.5 and $1.7 \pm 0.1 \mathrm{~nm}$ for WLIP and $2.1 \pm 0.1 \mathrm{~nm}$ for tolaasin $\mathrm{I}$. The antifungal activity of WLIP together with the finding that avirulent morphological variants of $P$. reactans lack WLIP production suggests that WLIP may play an important role in the interaction of the producing bacterium $P$. reactans and cultivated mushrooms.

Additional keywords: Pseudomonas tolaasii.

Brown blotch of Agaricus bisporus and the yellowing of Pleurotus ostreatus are major diseases of these cultivated mushrooms caused by Pseudomonas tolaasii (Paine 1919). Besides $P$. tolaasii, other bacteria account for symptom development on the above hosts. $P$. reactans, known in literature for its use in the "white line" assay for the specific identification of $P$. tolaasii (Wong and Preece 1979), was demonstrated to be involved in disease development in the cultivated mushrooms

Corresponding author: Nicola S. Iacobellis; E-mail: iacobellis@unibas.it

This paper is dedicated to the memory of Gianfranco Menestrina.

* The $\boldsymbol{e}$-Xtra logo stands for "electronic extra" and indicates that Figure 1 appears in color online.
Agaricus bisporus and Pleurotus spp. (Iacobellis and Lo Cantore 1997, 1998b; Lo Cantore 2001; Lo Cantore and Iacobellis 2002; Iacobellis and Lo Cantore 2003) including P. eryngii (Iacobellis and Lo Cantore 1998a, 2003), a mushroom species cultivated in southern Italy.

The pathogenicity of some strains of $P$. reactans has been reported in independent studies (Goor et al. 1986; Kim et al. 1995; Wells et al. 1996), but the pathogenicity of this bacterium was neglected for a long time. Recently, additional bacteria, such as $P$. costantinii sp. nov. (Munsch et al. 2002) or Pseudomonas sp. strain NZ17 (Godfrey et al. 2001), a bacterium apparently closely related to $P$. syringae, have been reported to be the causal agents of brown blotch disease of Agaricus bisporus.

Strains of $P$. reactans produce an extracellular substance called the white line-inducing principle (WLIP), which has the ability to interact with tolaasin I, a toxic lipodepsipeptide (LDP) produced in vitro by virulent strains of $P$. tolaasii, and forms a white precipitate in the white line assay (Wong and Preece 1979). WLIP, biological features of which are substantially unknown, is a LDP with a molecular weight of $1,125 \mathrm{Da}$ composed of an $\mathrm{N}$-terminal $\beta$-hydroxydecanoic acid and a peptide moiety of nine amino acids, six of which are in the D-form. The molecule contains a lactone ring between D-allo-threonine $\left(\mathrm{D}-\mathrm{Thr}^{3}\right.$ ) and N-terminal L-isoleucine (Ileu ${ }^{9}$ ) (MortischireSmith et al. 1991). WLIP is structurally similar to another LDP called viscosin (Laycock et al. 1991; Neu et al. 1990), except for the chirality of leucine in position 5 that it is D- in WLIP and L- in viscosin. The latter substance is a potent biosurfactant that appears important in the biology of the pectolytic $P$. fluorescens $\mathrm{SH} 10-3 \mathrm{~B}$ strains responsible for broccoli head rot (Laycock et al. 1991). Interestingly, viscosin does not produce any white precipitate when coincubated with purified tolaasin I (Rainey et al. 1992).

The fact that avirulent morphological variants of $P$. reactans were shown to lack WLIP production (Iacobellis and Lo Cantore 2003; Lo Cantore 2001) suggests that WLIP may play an important role in the virulence and pathogenicity of the above bacterium. The lack of information, either on the biological features of WLIP or on its role in virulence and pathogenicity and the mechanisms involved, prompts us to characterize it also in comparison to tolaasin I which is considered as the main virulence factor of $P$. tolaasii, as being responsible for the symptom development on mushrooms (Rainey et al. 1991; 1992; SolerRivas et al. 1999). It was demonstrated to have antifungal activ- 
ity, and this trait is apparently due to the ability of this molecule to disrupt cell membrane functions by the transmembrane pore formation (Brodey et al. 1991; Hutchinson and Johnstone 1993; Lo Cantore et al. 2003b; Rainey et al. 1991).

Here, we report on the results regarding the toxicity of WLIP in comparison with tolaasin I, either on whole sporophores or pseudo-tissue blocks of Agaricus bisporus, as well as on the antimicrobial activity toward fungi, chromista, and bacteria. Furthermore, the haemolytic activity of the above substances was analyzed and compared. Some preliminary results have already been reported (Lo Cantore 2001; Lo Cantore et al. 2003a). The determination of antifungal activity of WLIP and its mechanism of action may lead to a better understanding of the role of the above metabolite in the virulence of $P$. reactans.

\section{RESULTS}

\section{General characteristics}

\section{of $P$. reactans NCPPB1311 and LDP purification.}

Strains NCPPB1311 and NCPPB2192 showed the LOPAT characteristics of the group $\mathrm{V}_{\mathrm{a}}$ of Pseudomonas fluorescens (Lelliott and Stead 1987) and the features of $P$. reactans and $P$. tolaasii, respectively, to oxidate nutrients, as evaluated with the differential nutritional scheme of Goor and associates (1986). Furthermore, generated C-source utilization profiles of the above bacteria, evaluated with the computer-assisted system Biolog (Biolog Inc., Hayward, CA, U.S.A.), were different and clearly distinguished $P$. reactans from $P$. tolaasii (Lo Cantore 2001).

Table 1. Antimicrobial activity ${ }^{\mathrm{a}}$ of white line-inducing principle (WLIP) and tolaasin I towards fungi and chromista

\begin{tabular}{|c|c|c|c|}
\hline \multirow[b]{2}{*}{ Fungi and chromista } & \multirow[b]{2}{*}{ No. strains } & \multicolumn{2}{|c|}{ M.I.Q. $(\mu \mathrm{g})$} \\
\hline & & Tolaasin I & WLIP \\
\hline Fusarium solani & 3 & $0.32^{\mathrm{b}}$ & $5.12^{\mathrm{b}}$ \\
\hline F. oxysporum & 1 & 0.32 & 2.56 \\
\hline F. graminearum & 1 & 0.16 & $-^{\mathrm{c}}$ \\
\hline Sclerotinia sclerotiorum & 2 & $0.32^{\mathrm{b}}$ & $1.28^{\mathrm{b}}$ \\
\hline S. minor & 1 & 0.16 & 0.64 \\
\hline Sclerotium rolfsii & 1 & 0.32 & $-^{\mathrm{c}}$ \\
\hline Rhizoctonia solani & 1 & 0.08 & 0.64 \\
\hline Trichoderma viride & 1 & 0.16 & 1.28 \\
\hline Alternaria alternata & 1 & 0.64 & $\mathrm{ND}^{\mathrm{d}}$ \\
\hline Verticillium dahliae & 1 & 0.16 & 1.28 \\
\hline Phoma lingam & 1 & 0.16 & 2.56 \\
\hline Septoria tritici & 1 & 0.64 & ND \\
\hline Botrytis cinerea & 2 & $0.16^{\mathrm{b}}$ & $1.28^{\mathrm{b}}$ \\
\hline Phytopthora nicotianae & 1 & 0.32 & $-^{\mathrm{c}}$ \\
\hline P. citrophthora & 1 & 0.32 & $-^{\mathrm{c}}$ \\
\hline Armillaria mellea & 2 & $0.32^{\mathrm{b}}$ & $2.56^{\mathrm{b}}$ \\
\hline Heterobasidion annosum & 2 & $0.16^{\mathrm{b}}$ & $1.28^{\mathrm{b}}$ \\
\hline Agaricus bisporus & 2 & $0.08^{\mathrm{b}}$ & $1.28^{\mathrm{b}}$ \\
\hline Pleurotus eryngii & 3 & $0.32^{\mathrm{b}}$ & $2.56^{\mathrm{b}}$ \\
\hline Pleurotus ostreatus & 2 & $0.16^{\mathrm{b}}$ & $1.28^{\mathrm{b}}$ \\
\hline Pleurotus nebrodensis & 1 & 0.32 & $-^{c}$ \\
\hline Lentinus edodes & 2 & $0.32^{\mathrm{b}}$ & $1.28^{\mathrm{b}}$ \\
\hline Geotrichum candidum & 1 & $-^{\mathrm{e}}$ & $-^{\mathrm{c}}$ \\
\hline Rhodotorula pilimanae & 1 & 0.64 & $c^{\mathrm{c}}$ \\
\hline Candida albicans & 1 & 5.12 & $-^{f}$ \\
\hline C. parapsilosis & 1 & g & $-{ }^{\mathrm{f}}$ \\
\hline Malassezia pachydermatis & 1 & $\_\mathrm{g}$ & $-{ }^{\mathrm{f}}$ \\
\hline Cryptococcus neoformans & 1 & 2.56 & $-{ }^{\mathrm{f}}$ \\
\hline 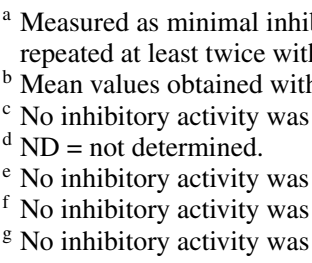 & $\begin{array}{l}\text { ory quantity } \\
\text { aree replicates } \\
\text { e different str } \\
\text { served with } 1\end{array}$ & $\begin{array}{l}\text { Q.). The exp } \\
\text {. } \\
\mu \mathrm{g} \text { of WLIP }\end{array}$ & ents wer \\
\hline
\end{tabular}

$P$. reactans NCPPB1311 and $P$. tolaasii NCPPB2192 formed a white precipitate in King's medium $B(\mathrm{~KB})$ agar when grown one toward the other and caused brown lesions on tissue blocks of Agaricus bisporus. P. reactans NCPPB1311 was less virulent than $P$. tolaasii NCPPB2192 (results not shown).

Cultures (48 h old) of $P$. reactans NCPPB1311, assayed for antimicrobial activity on $\mathrm{KB}$ medium, showed an activity rate of 400 units/ml toward Bacillus megaterium but did not inhibit the growth of Rhodotorula pilimanae. On the contrary, cultures of $P$. tolaasii NCPPB2192 showed an activity of 3,200 and 800 units/ml toward Bacillus megaterium ITM100 strains and $R$. pilimanae ATTC26423, respectively.

The chemical nature of WLIP and tolaasin I was ascertained by comparing their ${ }^{1} \mathrm{H}$ nuclear magnetic resonance (NMR) and mass spectra (MS) data to those reported in literature (Mortishire-Smith et al. 1991; Nutkins et al. 1991). Furthermore, the absolute stereochemistry of WLIP was also confirmed by X-ray analysis, which gave WLIP crystallographic data in perfect agreement to those described for the LDP (Han et al. 1992).

\section{Antimicrobial activity of WLIP produced by $P$. reactans NCPPB1311.}

Crystalline WLIP and high-performance liquid chromatography (HPLC)-grade tolaasin I showed a different capability to inhibit target microorganisms (Tables 1 and 2). In particular, WLIP inhibited the growth of Bacillus megaterium ITM100 with a minimal inhibitory quantity (M.I.Q.) of $0.32 \mu \mathrm{g}$ (Table 2). The M.I.Q. of tolaasin I toward Rhodotorula pilimanae ATCC26423 and Escherichia coli ITM103 was $0.64 \mu \mathrm{g}$, whereas against Bacillus megaterium ITM100, it was $0.04 \mu \mathrm{g}$ (Tables 1 and 2).

Further antimicrobial assays showed that crystalline WLIP inhibited the growth of fungi, chromista, and gram-positive bacteria at M.I.Q. values higher than those of tolaasin I and, on the contrary, did not inhibit the growth of most of the tested gram-negative bacteria (Table 1 and 2). The only exception was the strain of Erwinia carotovora subsp. carotovora that

Table 2. Antimicrobial activity ${ }^{\mathrm{a}}$ of white line-inducing principle (WLIP) and tolaasin I towards bacteria

\begin{tabular}{|c|c|c|c|}
\hline \multirow[b]{2}{*}{ Bacteria } & \multirow[b]{2}{*}{ No. strains } & \multicolumn{2}{|c|}{ M.I.Q. $(\mu \mathrm{g})$} \\
\hline & & Tolaasin I & WLIP \\
\hline \multicolumn{4}{|l|}{ Gram positive } \\
\hline Bacillus megaterium & 1 & 0.04 & 0.32 \\
\hline Rhodococcus fascians & 2 & $0.16^{\mathrm{b}}$ & $1.28^{\mathrm{b}}$ \\
\hline Curtobacterium flaccunfaciens & 1 & 0.16 & 0.64 \\
\hline $\begin{array}{l}\text { Clavibacter michiganensis } \\
\text { subsp. sepedonicus }\end{array}$ & 1 & 0.32 & 0.64 \\
\hline $\begin{array}{l}\text { C. michiganensis subsp. } \\
\text { michiganensis }\end{array}$ & 2 & $0.32^{\mathrm{b}}$ & $0.64^{\mathrm{b}}$ \\
\hline Gram negative & & & \\
\hline Escherichia coli & 1 & 0.64 & $-^{\mathrm{c}}$ \\
\hline $\begin{array}{l}\text { Pseudomonas syringae pv. } \\
\text { phaseolicola }\end{array}$ & 1 & 1.28 & $-^{\mathrm{c}}$ \\
\hline P. tolaasii & 1 & $-^{\mathrm{d}}$ & $-^{c}$ \\
\hline P. reactans & 1 & 1.28 & $-^{\mathrm{c}}$ \\
\hline P. corrugata & 1 & 0.64 & $-^{\mathrm{c}}$ \\
\hline Agrobacterium tumefaciens & 1 & 0.64 & $-^{\mathrm{c}}$ \\
\hline Erwinia herbicola & 1 & 0.64 & $-^{\mathrm{c}}$ \\
\hline E. carotovora subsp. carotovora & 1 & 0.32 & 5.12 \\
\hline $\begin{array}{l}\text { Xanthomonas campestris pv. } \\
\text { phaseoli }\end{array}$ & 1 & 1.28 & $-^{\mathrm{c}}$ \\
\hline
\end{tabular}


was inhibited at M.I.Q. $=5.12 \mu \mathrm{g}$ (Table 2$)$. No activity, either toward the yeast $R$. pilimanae or Candida albicans, $C$. parapsilosis, Malassezia pachydermatis, and Cryptococcus neoformans, yeast-like fungi responsible for systemic and cutaneous mycoses in animals and humans, was observed even when 10.24 or $25.00 \mu \mathrm{g}$ of the substance was used.

Tolaasin I inhibited the growth of filamentous fungi and gram-positive bacteria and showed a small activity toward some gram-negative bacteria (Table 2). Of particular interest is the activity shown by tolaasin I toward some soil-inhabiting phytopathogenic fungi and chromista and the cultivated mushrooms Agaricus bisporus, Pleurotus spp., and Lentinus edodes. The M.I.Q. toward fungi and chromista ranged between 0.08 and $0.64 \mu \mathrm{g}$ with strains of Agaricus bisporus and Rhizoctonia solani, the most sensitive among fungi used in this study. Besides Bacillus megaterium, other phytopathogenic gram-positive bacteria also were quite sensitive to the toxin, with a M.I.Q. ranging from 0.04 to $0.32 \mu \mathrm{g}$ (Table 2). Among gramnegative bacteria, as expected, the strain of $P$. tolaasii was resistant to tolaasin I. In contrast to previous studies, tolaasin I was found to inhibit the growth of gram-negative bacteria belonging to genera Erwinia, Escherichia, Agrobacterium, Pseudomonas, and Xanthomonas. E. carotovora subsp. carotovora, E. herbicola, Escherichia coli, A. tumefaciens, $P$. syringae pv. phaseolicola, $P$. corrugata, $X$. campestris pv. phaseoli, and $P$. reactans strains showed a M.I.Q. ranging from 0.32 to $1.28 \mu \mathrm{g}$ (Table 2). Furthermore, tolaasin I inhibited the growth of $C$. albicans and $C$. neoformans, but the sensitivity of the above fungi was lower when compared with that of phytopathogenic fungi. Under the applied assay conditions, no activity regarding the growth of $C$. parapsilosis or Malassezia pachydermatis was observed.

\section{Effect of WLIP on tissue blocks}

and whole sporophores of Agaricus bisporus.

Assays of the two LDP WLIP and tolaasin I on tissue blocks of Agaricus bisporus showed that the deposition on their surface of a drop of solution containing $1.28 \mu \mathrm{g}$ of WLIP caused brown sunken lesions (Fig. 1). Under the same assay condi-

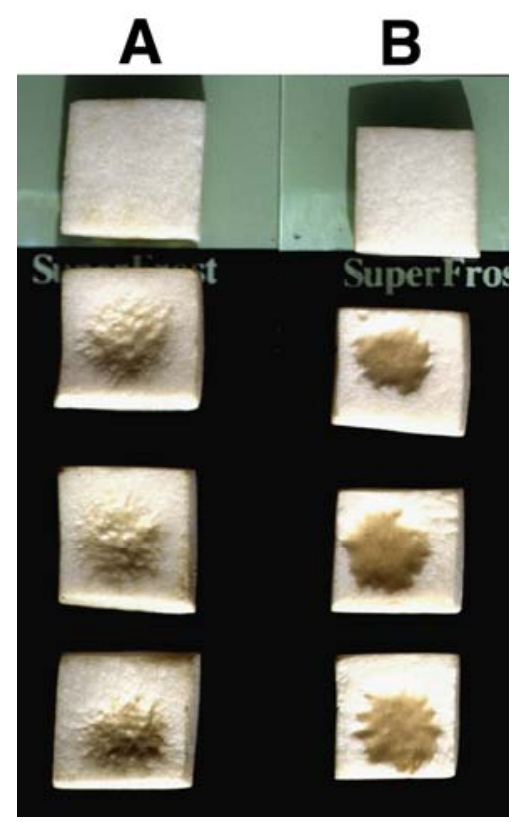

Fig. 1. Brown lesions on tissue blocks of Agaricus bisporus (lower three blocks in each treatment), caused by deposition of $5-\mu 1$ solutions containing A, $5.12 \mu \mathrm{g}$ of white line-inducing principle and $\mathbf{B}, 0.64 \mu \mathrm{g}$ of tolaasin I, respectively. On upper blocks, $5 \mu \mathrm{l}$ of sterile water was deposited. tion, a similar effect was observed when drops of solution containing $0.08 \mu \mathrm{g}$ of tolaasin I were used. Similar results were obtained when such LDP were deposited on the surface of whole sporophore caps (data not shown).

\section{Haemolytic activity}

of WLIP and the effect of osmoprotectants.

Both WLIP and tolaasin I caused red blood cell (RBC) lysis. In both the agarose plate assay and the assay in solution, the haemolytic activity appeared to be higher for WLIP than for tolaasin I. The minimal haemolytic quantity (M.H.Q.) of WLIP and tolaasin I evaluated in the agarose plate assay were 0.64 and $2.56 \mu \mathrm{g}$, respectively (Table 3). Haemolytic activity of tolaasin I, as opposed to WLIP, appeared to be temperature dependent (Table 3 ). In the case of WLIP, incubation at 25 or $37^{\circ} \mathrm{C}$ did not influence the bovine RBC lysis, which in both treatments showed the same feature as estimated by the diameter of the clear zone. In contrast, tolaasin I was more active at $37^{\circ} \mathrm{C}$. The temperature effect was ob-

Table 3. Minimal haemolytic quantity of white line-inducing principle (WLIP) and tolaasin I at different temperatures

\begin{tabular}{|c|c|c|c|c|}
\hline \multirow{3}{*}{$\begin{array}{l}\text { Lipodepsipeptide } \\
\text { quantity }(\mu \mathrm{g})\end{array}$} & \multicolumn{4}{|c|}{ Average diameter of the haemolysis area $(\mathrm{mm})^{\mathrm{a}}$} \\
\hline & \multicolumn{2}{|c|}{ Tolaasin I } & \multicolumn{2}{|c|}{ WLIP } \\
\hline & $25^{\circ} \mathrm{C}$ & $37^{\circ} \mathrm{C}$ & $25^{\circ} \mathrm{C}$ & $37^{\circ} \mathrm{C}$ \\
\hline 10.24 & 8 & 16 & 24 & 24 \\
\hline 5.12 & 7 & 11 & 22 & 22 \\
\hline 2.56 & 7 & 7 & 18 & 18 \\
\hline 1.28 & 0 & 0 & 11 & 11 \\
\hline 0.64 & 0 & 0 & 9 & 9 \\
\hline 0.32 & 0 & 0 & 0 & 0 \\
\hline
\end{tabular}

${ }^{a}$ Determined in agarose plate assay. The experiments were repeated at least twice with three replicates.

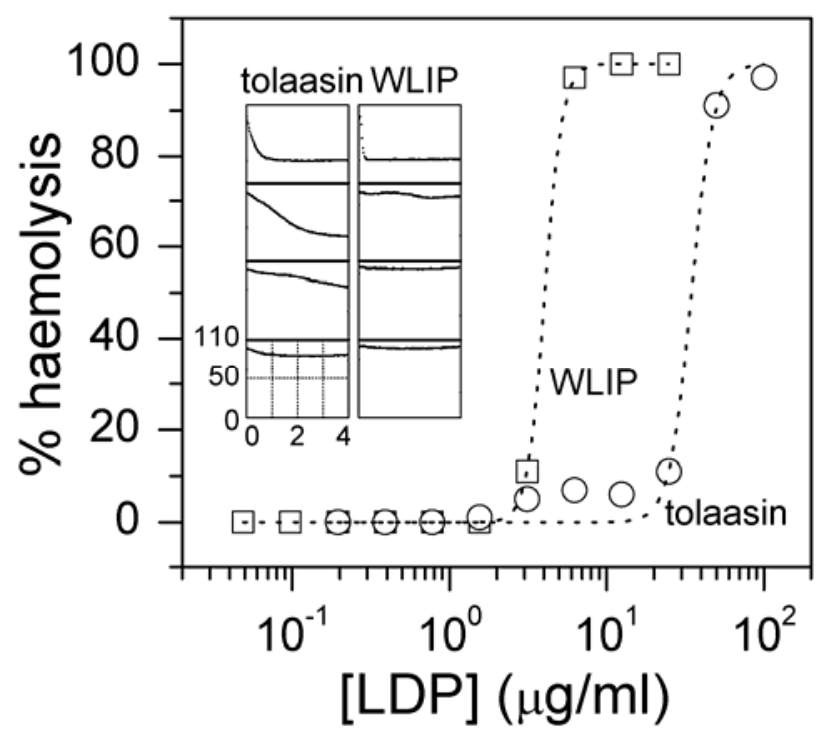

Fig. 2 . Dose dependence of the haemolytic activity of white line-inducing principle (WLIP) (squares) and tolaasin I (circles) after $4 \mathrm{~h}$ at room temperature. Dotted lines are best-fit experimental data points with Hill equation. Hill coefficients are 6.3 and 8.0 for tolaasin I and WLIP, respectively. Inset: Set of traces recorded on the microplate reader of kinetics of haemolysis of red blood cells (RBC) exposed to two-step sequential dilutions of tolaasin I (left) and WLIP (right), from top to bottom. Starting concentration (top panels) were $100 \mu \mathrm{g} / \mathrm{ml}$ tolaasin I and $6.25 \mu \mathrm{g} / \mathrm{ml}$ WLIP. The decrease of turbidity over time indicated the disappearance of intact RBC. All panels have the same linear axis, ranging from 0 to $4 \mathrm{~h}$ and from 0 to $110 \mathrm{mOD}$ for $x$ and $y$ axes, respectively. 
served at quantities of 10.24 or $5.12 \mu \mathrm{g}$ but not at the M.H.Q. $(2.56 \mu \mathrm{g})$ of the toxin.

In the solution assay, both tolaasin I and WLIP caused human RBC lysis (Fig. 2). WLIP was more effective than tolaasin $\mathrm{I}$ with regard to both $\mathrm{C}_{50}$ (i.e., the minimal concentration able to cause $50 \%$ haemolysis, which was close to 4.3 and $34.6 \mu \mathrm{g} / \mathrm{ml}$ for WLIP and tolaasin I, respectively) and of the haemolysis rate (Fig. 2, inset). The Hill coefficient associated to the formation of the active unit appeared to be higher for WLIP $(8 \pm 2)$ than for tolaasin I $(6 \pm 1)$.

The haemolytic activity of both LDP can be prevented by adding osmoticants of adequate dimensions to the external medium. The results reported in Figure 3 suggest, at a concentration corresponding to $1.5 \times \mathrm{C}_{50}$, a pore radius between $1.5 \pm$ 0.1 and $1.7 \pm 0.1 \mathrm{~nm}$ for WLIP and $2.1 \pm 0.1 \mathrm{~nm}$ for tolaasin I.

The small molecular size of LDP suggests that such large pores could be formed by an aggregate of monomers, which is also consistent with the large Hill coefficients observed. The structure of the pore formed by WLIP appeared to be less stable with a more pronounced dependence on toxin concentration. In fact, at a higher toxin dose $\left(2 \times \mathrm{C}_{50}\right)$, a bigger osmoticant is necessary for full protection of RBC from lysis (Fig. 3, right bottom panel).

\section{DISCUSSION}

Growth in $\mathrm{KB}$ medium resulted in the production of high levels of the LDP WLIP and tolaasins by $P$. reactans NCPPB1311 and P. tolaasii NCPPB2192, respectively. However, the yield of WLIP (about $169 \mathrm{mg} / \mathrm{l}$ ) was more than tenfold higher than that of the tolaasin mixture (about $13 \mathrm{mg} / \mathrm{l}$ ). Further purification of tolaasin by HPLC confirmed the previous indication (Shirata et al. 1995) that P. tolaasii, besides the already known tolaasins I and II (Nutkins et al. 1991), produced in vitro other related metabolites. Results on the chemical and biological characterization of tolaasins A to E, the new analogs of tolaasin I and II, have been recently reported (Bassarello et al. 2004; Lazzaroni et al. 2003).

The antimicrobial assays of crystalline WLIP and HPLCgrade tolaasin I showed also that WLIP is a LDP active in the growth inhibition of bacteria and fungi and confirmed this activity for tolaasin I, as previously reported (Rainey et al. 1991, 1992). Generally, the antimicrobial activity of tolaasin I was higher than that of WLIP. The gram-positive bacterium Bacillus megaterium proved to be the microorganism most sensitive to both tolaasin I and WLIP with a M.I.Q of 0.04 and $0.32 \mu \mathrm{g}$, respectively. Also the other gram-positive bacteria used in this

\section{tolaasin}
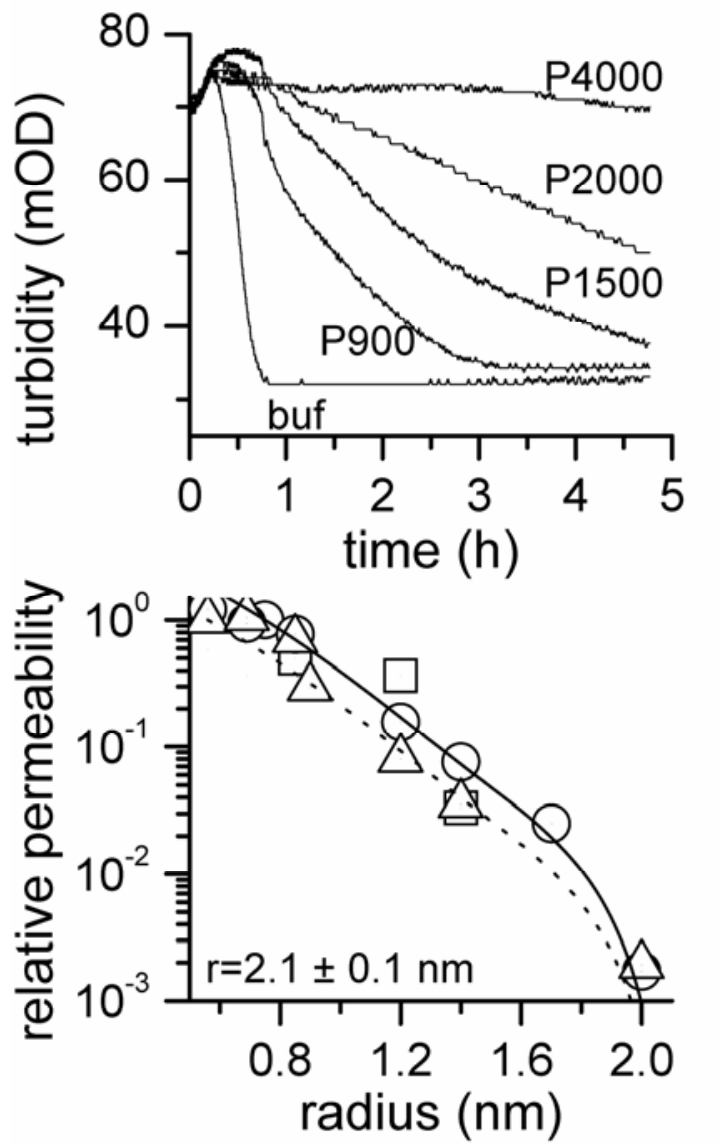

WLIP
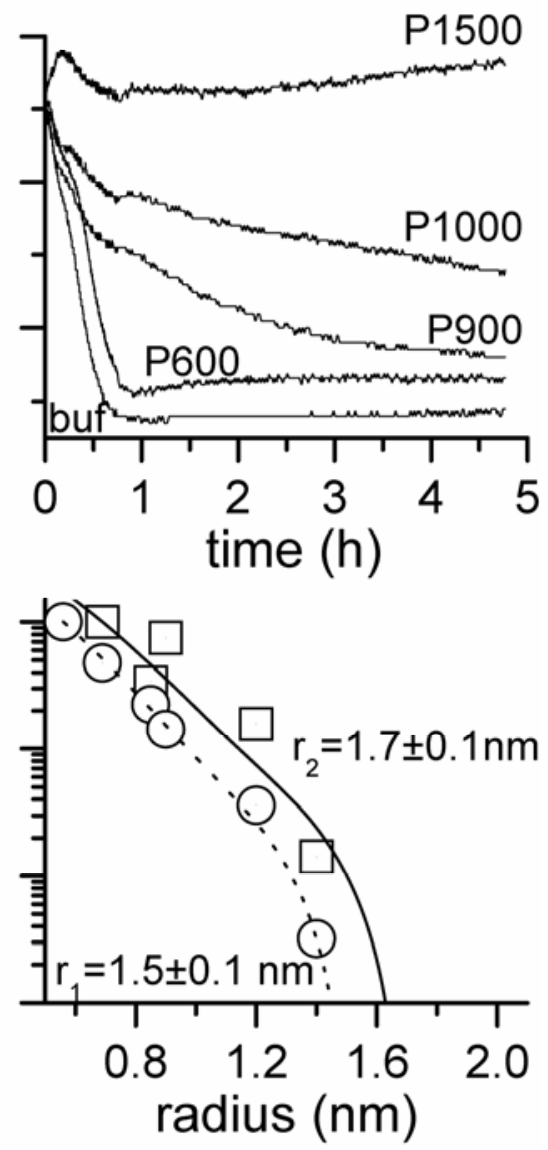

Fig. 3. Haemolysis in the presence of osmotic protectants and Renkin fit. Upper panels: Representative traces of decrease in turbidity of a red blood cell suspension in the presence of different external polyethylene glycol (PEG) osmolites and constant lipodepsipeptide (LDP) concentrations (i.e., 100 and 6.25 $\mu \mathrm{g} / \mathrm{ml}$ for tolaasin I and white line-inducing principle (WLIP), respectively). PEG size is indicated next to each trace. Lower panels: Renkin representation of data collected in experiments similar to those reported in the upper panels. Curves through points are best fits according to Renkin equation (Schultz and Solomon 1961; Ginsburg and Stein 1987), which gives a pore radius for tolaasin I of $2.1 \pm 0.1 \mathrm{~nm}$. This value is not dependent on LDP concentration, at least at the concentrations used in this study (i.e., 50 to $100 \mu \mathrm{g} / \mathrm{ml}$ ): the dotted lines represent the best fit of data collected at $76 \mu \mathrm{g} / \mathrm{ml}$ of tolaasin I (triangles, $2 \times$ $\mathrm{C}_{50}$ ), solid lines refer to best fit of data collected at 50 (squares, $1.5 \times \mathrm{C}_{50}$ ) and $100 \mu \mathrm{g} / \mathrm{ml}\left(\right.$ circles, $3 \times \mathrm{C}_{50}$ ) of tolaasin I. On the other hand, WLIP shows different values of pore radii, ranging from $1.5 \pm 0.1$ to $1.7 \pm 0.1 \mathrm{~nm}$, depending on toxin concentration. Dotted lines are the best fit of data collected at 6.25 $\mu \mathrm{g} / \mathrm{ml}$ of WLIP (circles, $1.5 \times \mathrm{C}_{50}$ ), and solid lines refer to best fit of data collected at $9 \mu \mathrm{g} / \mathrm{ml}$ of WLIP $\left(\mathrm{squares}, 2 \times \mathrm{C}_{50}\right)$. 
study were inhibited by both LDP (Table 2). The tested gramnegative bacteria were inhibited by tolaasin I but not by WLIP, except E. carotovora subsp. carotovora (Table 2).

Generally, fungi and chromista were inhibited by both LDP and, on average, tolaasin I was about eight- to tenfold more active than WLIP. Of interest is the fact that strains of Agaricus bisporus, Pleurotus ostreatus, $P$. eryngii, and Lentinus edodes were the most sensitive to both LDP. The assays of the two substances on tissue blocks and whole sporophores of Agaricus bisporus confirmed the antifungal activity of both WLIP and tolaasin I, which in fact, both caused significant brown and sunken lesions on the surface of the above Agaricus tissue blocks and on whole sporophores, although at different concentrations. Similar mushroom-tissue alterations were observed when WLIP solution was about 15 times more concentrated.

The results of this study clearly demonstrated that WLIP, like other LDP of bacterial origin (Bender et al. 1999), is toxic towards fungi, although the activity of this compound is generally lower than tolaasin I. The above findings suggest that WLIP, as already reported for tolaasin I (Brodey et al. 1991; Hutchison and Johnstone 1993; Rainey et al. 1991; 1992), may be important in the interaction with mushrooms. When considering the observed lower antifungal activity of WLIP, it is also necessary to remember that, at least in vitro, $P$. reactans NCPPB1311 produced a quantity of WLIP that is more than ten times higher than the quantity of tolaasin I produced by $P$. tolaasii-type strain NCPPB2192. It could be hypothesized that the lower antifungal activity of WLIP is compensated by the higher quantity produced in culture. So far P. tolaasii NCPPB1116, used by Rainey and associates (1991) and grown in conditions different from those adopted in this study, appears to produce higher levels of tolaasin. However, data on the possible generally different levels of LDP production in culture by strains of $P$. reactans and $P$. tolaasii are not available, and this feature needs to be confirmed with a representative number of strains.

Haemolysis assays showed that WLIP, as already reported for tolaasin I (Rainey et al. 1991), caused RBC lysis. This finding is in accord with the haemolytic activity of bacteria associated to cultivated mushrooms, including $P$. reactans, recently reported by Munsch and Alatossava (2002b). However, the assays clearly indicated the higher haemolytic activity of WLIP when compared with tolaasin I. Under assay conditions, the M.H.Q. of WLIP was more than four times higher than that of tolaasin I. WLIP and tolaasin I appear to cause RBC lysis through a colloid-osmotic shock, apparently due to transmembrane pore formation. In fact, in parallel studies, both LDP were also demonstrated to form channels in lipid vesicles (Coraiola et al., in press; Lo Cantore et al. 2003b).

The haemolytic activity of tolaasin I was, as previously reported (Rainey et al. 1991), temperature dependent. However, this effect was not observed in the case of WLIP. The higher temperatures might increase both the rate of tolaasin diffusion in solution and the membrane fluidity, facilitating the process of membrane destabilization by tolaasin I.

Haemolytic assays in aqueous solution showed that the M.H.Q. was about 3 and $12 \mu \mathrm{g} / \mathrm{ml}$ for WLIP and tolaasin I, respectively. In similar assays, Rainey and associates (1991) reported that a $1.5 \mu \mathrm{g} / \mathrm{ml}$ solution of tolaasin I determined a haemolytic effect. However, the latter experiments were performed on horse erythrocytes, at lower concentrations, and at $37^{\circ} \mathrm{C}$.

A theoretical analysis of the protection experiments with the Renkin equation made it possible to assess the functional pore radius, which was between $1.5 \pm 0.1$ and $1.7 \pm 0.1 \mathrm{~nm}$ for WLIP and $2.1 \pm 0.1 \mathrm{~nm}$ for tolaasin I, respectively. These radius values are similar to those found for other LDP (Dalla Serra et al. 1999). The functional pore radius of tolaasin I, previously estimated as being smaller ( 0.9 to $1.0 \mathrm{~nm}$ ), according to reports by Rainey and associates (1991), could depend on the much lower tolaasin I concentration used in the above experiments. The small molecular size of LDP suggests that such large pores could be formed by an aggregate of monomers and, therefore, a pore diameter possibly dependent on the toxin concentration. For the smaller WLIP, this dependency is more marked and, at a higher toxin dose, a bigger osmoticant is necessary in order to fully protect RBC from lysis.

In conclusion, the findings reported in this paper indicate that WLIP is toxic to fungal as well as other cells. The activity of the above substances is possibly mediated by transmembrane pore formation, as demonstrated in the case of other LDP of bacterial origin (Bender et al. 1999; Menestrina et al. 2003). The antifungal activity of WLIP suggests that the substance-produced by $P$. reactans in such relatively high amounts, at least in vitro-may be important for the virulence and pathogenicity of the bacterium. The observation that phenotypic variants of $P$. reactans strains are avirulent and do not produce WLIP (Iacobellis and Lo Cantore 2003; Lo Cantore 2001) support the possibility that the latter compound may play an important role in the interaction of $P$. reactans with cultivated mushrooms. However, the high heterogeneity of the so-called $P$. reactans (i.e., bacterium associated with cultivated mushrooms and producing white precipitates when grown toward P. tolaasii) for several characteristics (Goor et al. 1986), including virulence (Lo Cantore 2001; Munsch and Alatossava 2002a), pyoverdine production (Munsch et al. 2000), and oxidative ability of potential nutrients evaluated with the computer-assisted system Biolog as well as repetitive extragenic palindromic-polymerase chain reaction fingerprinting (Lo Cantore 2001; N. S. Iacobellis et al. unpublished data), prompt further studies for a better characterization of the novel mushroom pathogen for an adequate taxonomic allocation.

\section{MATERIALS AND METHODS}

\section{General characteristics of $P$. reactans NCPPB1311.}

$P$. reactans NCPPB1311 and $P$. tolaasii NCPPB2192 were maintained under lyophilized conditions at $4^{\circ} \mathrm{C}$. Subcultures were obtained by growing bacteria for $48 \mathrm{~h}$ on KB (King et al. 1954). Before use, the above bacteria were evaluated for the characteristics reported in the LOPAT (Lelliott and Stead 1987) and nutritional schemes (Goor et al. 1986), for the white line assay (Wong and Preece 1979), and for pathogenicity on tissue blocks of Agaricus bisporus, prepared following the procedure reported by Ercolani (1970). Furthermore, the bacteria were evaluated for their ability to oxidize carbon sources by utilizing computer-assisted Biolog (Biolog Inc., Hayward, CA, U.S.A.).

\section{Purification of WLIP produced by $P$. reactans NCPPB1311.}

$P$. reactans NCPPB1311 and $P$. tolaasii NCPPB2192 were grown at $25^{\circ} \mathrm{C}$ under shaking $(180 \mathrm{rpm})$ in 500-ml Erlenmeyer flasks filled with $150 \mathrm{ml}$ of liquid $\mathrm{KB}$ medium inoculated with $1.5 \mathrm{ml}$ of a bacterial suspension containing about $10^{8} \mathrm{CFU} / \mathrm{ml}$. Every 24-h incubation, culture aliquots were centrifuged $(20,000 \times g$ for $15 \mathrm{~min}$.), and subsequently, supernatants were filtered through Millipore membranes $(0.22$ $\mu \mathrm{m})$. The resulting filtrates were evaluated for the presence of antimicrobial activity on Bacillus megaterium ITM100 and Rhodotorula pilimanae ATTC26423, according to a procedure reported by Lavermicocca and associates (1997). After 24 or $48 \mathrm{~h}$, depending on the target organism, growth inhibition was evaluated, and the antimicrobial activity was expressed as units per milliliter. A unit is the quantity of the 
metabolite dissolved in $10 \mu \mathrm{l}$ that is capable of inhibiting the growth of the target microorganism in the area of deposition of the 10- $\mu$ l drop (Sinden et al. 1971).

Tolaasins were isolated and purified from the cell-free culture filtrate, according to a modification of the method described by Peng (1986). The resulting tolaasin preparations, active in the inhibition of Bacillus megaterium, were further purified by reversed-phase HPLC on a Shimadzu instrument equipped

Table 4. Fungi, chromista, and bacteria used in the antimicrobial assays in this study

\begin{tabular}{|c|c|c|}
\hline Target organisms & Strains & Source $^{a}$ \\
\hline \multicolumn{3}{|l|}{ Fungi and chromista } \\
\hline Fusarium solani & $109,114,140$ & A. Zoina \\
\hline F. oxysporum & 219 & A. Zoina \\
\hline F. graminearum & ITM022016 & A. Logrieco \\
\hline Sclerotinia sclerotiorum & 853,902 & A. Logrieco \\
\hline S. minor & 1185 & A. Logrieco \\
\hline Sclerotium rolfsii & 1401 & A. Logrieco \\
\hline Rhizoctonia solani & 1583 & A. Logrieco \\
\hline Trichoderma viride & ITM2685 & A. Logrieco \\
\hline Alternaria alternata & ITM2063 & A. Logrieco \\
\hline Verticillium dahliae & ITM1910 & A. Logrieco \\
\hline Phoma lingam & ITM2078 & A. Logrieco \\
\hline Septoria tritici & ITM2955 & A. Logrieco \\
\hline Botrytis cinerea & 1636, ITM3715 & $\begin{array}{l}\text { A. Zoina, } \\
\text { A. Logriecc }\end{array}$ \\
\hline Phytopthora nicotianae & USB-F1 & USB \\
\hline Phytophthora citrophthora & USB-F2 & USB \\
\hline Armillaria mellea & 196,200 & N. Luisi \\
\hline Heterobasidium annosum & 1,2 & N. Luisi \\
\hline Agaricus bisporus & DS222, DS410 & D. Sisto \\
\hline Pleurotus eryngii & $\begin{array}{l}\text { DS77, DS256, } \\
\text { DS } 270\end{array}$ & D. Sisto \\
\hline Pleurotus ostreatus & DS226, DS245 & D. Sisto \\
\hline Pleurotus nebrodensis & DS260 & D. Sisto \\
\hline Lentinus edodes & DS46, DS93 & D. Sisto \\
\hline Geotrichum candidum & ITM104 & ITM \\
\hline Rhodotorula pilimanae & ATCC26423 & ATCC \\
\hline Candida albicans & Di.S.B.A.22 & Di.S.B.A \\
\hline C. parapsilosis & Di.S.B.A.12 & Di.S.B.A \\
\hline Malassezia pachydermatis & Di.S.B.A.10 & Di.S.B.A \\
\hline Cryptococcus neoformans & Di.S.B.A.32 & Di.S.B.A \\
\hline \multicolumn{3}{|l|}{ Gram-positive bacteria } \\
\hline Bacillus megaterium & ITM100 & ITM \\
\hline Rhodococcus fascians & $\begin{array}{l}\text { NCPPB2551, } \\
\text { NCPPB3067 }\end{array}$ & NCPPB \\
\hline Curtobacterium flaccunfaciens & NCPPB559 & NCPPB \\
\hline $\begin{array}{l}\text { Clavibacter michiganensis } \\
\text { subsp. sepedonicus }\end{array}$ & NCPPB 2137 & NCPPB \\
\hline $\begin{array}{l}\text { Clavibacter michiganensis } \\
\text { subsp. michiganensis }\end{array}$ & DPP2, DPP3 & DPP \\
\hline \multicolumn{3}{|l|}{ Gram-negative bacteria } \\
\hline Escherichia coli & ITM103 & ITM \\
\hline $\begin{array}{l}\text { Pseudomonas syringae pv. } \\
\text { phaseolicola }\end{array}$ & NCPPB2571 & NCPPB \\
\hline P. tolaasii & NCPPB2192 & NCPPB \\
\hline$P$. reactans & NCPPB 1311 & NCPPB \\
\hline P. corrugata & NCPPB2445 & NCPPB \\
\hline Agrobacterium tumefaciens & NCPPB2437 & NCPPB \\
\hline Erwinia herbicola & ICMP9900 & ICMP \\
\hline E.carotovora subsp. carotovora & ICMP5702 & ICMP \\
\hline $\begin{array}{l}\text { Xanthomonas campestris pv. } \\
\text { phaseoli }\end{array}$ & ICMP3035 & ICMP \\
\hline
\end{tabular}

a A. Zoina of the Università di Napoli "Federico II", Italy; A. Logrieco of the Istituto di Scienze delle Produzioni Alimentari, CNR, Bari, Italy; USB = Universitá Degu Studi Della Basilicata; N. Luisi and D. Sisto of the Università di Bari, Italy; ITM = Istituto Tossine e Micotossine, Bari, Italy; ATCC = American Type Microrganism Collection, U.S.A.; Di.S.B.A. = Dipartimento di Sanità e Benessere Animale, Università di Bari, Italy; NCPPB = National Collection Plant Pathogenic Bacteria, U.K.; DPP = Dipartimento di Protezione delle piante, Università Tuscia, Viterbo, Italy; and ICMP = International Collection of Microrganism from Plants, Auckland, New Zealand. with HPLC pump LC-10 ADVP and UV-VIS detector SPD10AV. Analytical $(25 \mathrm{~cm} \times 4.6 \mathrm{~mm})$ and semipreparative $(25$ $\mathrm{cm} \times 10 \mathrm{~mm}$ ) Brownlee Aquapore RP-300 (C8) columns were used for the analysis and purification of the above preparations, respectively. A solvent system of water $(0.1 \%$ trifluoroacetic acid, vol/vol) and $\mathrm{CH}_{3} \mathrm{CN}$ with flow rates of 1.0 and 4.7 $\mathrm{ml} / \mathrm{min}$ for analytical and semipreparative columns, respectively, was used for elution. Preparation aliquots of $10 \mathrm{or} 1 \mu \mathrm{g}$ were used for preparative or analytical separation, respectively. All solvents were degassed before use. The fractions obtained from the semipreparative column were collected, partially dried under reduced pressure, and then, were lyophilized.

The isolation and purification of crude WLIP was performed according to the procedure reported by Mortishire-Smith and associates (1991). Crystalline WLIP was prepared by diffusing water vapor into a solution of crude WLIP in methanol.

The identity of both tolaasin I and WLIP was ascertained by NMR and MS. NMR spectra were recorded at 600 or 400 $\mathrm{MHz}$ in dimethyl sulfoxide (DMSO) $d_{6}$ on Bruker (Karlsruhe, Germany) spectrometers. The same solvent was used as internal standard. Electrospray ionization MS were recorded on a Perkin-Elmer (Norwalk, CT, U.S.A.) API 100 LC-MS, with a probe voltage of $5,300 \mathrm{~V}$ and a declustering potential of $50 \mathrm{~V}$. The absolute stereochemistry of WLIP was determined by Xray analysis carried out on a colorless crystal obtained as above. Data acquired on an Enraf-Nonius CAD4 (Delft, Holland) single-crystal diffratometer were compared with those previously described for the LDP (Han et al. 1992).

\section{Antimicrobial activity \\ of WLIP produced by $P$. reactans NCPPB1311.}

The antimicrobial activity of pure LDP has been evaluated on gram-positive and -negative bacteria, fungi, and chromista, according to the procedure reported by Lo Cantore (2001). The target organisms used in this study are reported in Table 4.

Crystalline WLIP was taken up in solution in DMSO (5 $\mathrm{mg} / \mathrm{ml})$, and then, twofold serial solutions in a buffer $(20 \mathrm{mM}$ Tris- $\mathrm{HCl}, 0.85 \% \mathrm{NaCl}, \mathrm{pH} 8$ ) containing 1,024, 512, 256, 64, 32 , and $16 \mu \mathrm{g} / \mathrm{ml}$ were prepared. For some assays, a solution containing $2,500 \mu \mathrm{g} / \mathrm{ml}$ was used.

HPLC-grade tolaasin I was taken up in solution in sterile distilled water $(1 \mathrm{mg} / \mathrm{ml})$, and then, twofold serial solutions in a buffer (20 mM Tris- $\mathrm{HCl}, 0.85 \% \mathrm{NaCl}, \mathrm{pH} 7)$ containing 128 , $64,32,16,8,4,2$, and $1 \mu \mathrm{g} / \mathrm{ml}$ were prepared.

Drops $(10 \mu \mathrm{l})$ of twofold serial dilutions of pure LDP solutions were deposited on the surface of Petri dishes containing $10 \mathrm{ml}$ of potato dextrose agar (PDA). After the drop had dried, plates were overlaid with $3 \mathrm{ml}$ of soft agar $(0.7 \%)$ in which the target bacterium had been suspended to a final concentration of about $10^{7} \mathrm{CFU} / \mathrm{ml}$.

Fungi and chromista were grown at $25^{\circ} \mathrm{C}$ on PDA plates, and after 3- or 5-days incubation, depending on the growth rate of the target microorganism, $10-\mu$ l drops of twofold serial dilutions of pure LDP solutions were deposited about $1 \mathrm{~cm}$ from the border of the colony.

After 24 or $48 \mathrm{~h}$ of incubation at $25^{\circ} \mathrm{C}\left(37^{\circ} \mathrm{C}\right.$ in the case of Escherichia coli), the lowest tested concentration capable of inhibiting the growth of the target organism was recorded.

The quantity of the substances still causing the inhibition of the target organisms was referred to as M.I.Q. and was expressed in micrograms. The experiments were repeated at least twice with three replications.

\section{Effect of WLIP on tissue blocks and whole sporophores of Agaricus bisporus.}

Tissue blocks of Agaricus bisporus, prepared following the procedure reported by Ercolani (1970), were treated with $5-\mu 1$ 
drops of twofold serial dilutions of LDP solutions prepared as above, were incubated at $25^{\circ} \mathrm{C}$, and were observed by eye after 16 and $40 \mathrm{~h}$. Drops of sterile distilled water were used as control. The assays were performed at least twice with three replicates.

Fresh sporophores of Agaricus bisporus were rinsed twice with distilled sterile water and were placed in aluminum trays previously sterilized in an autoclave at $121^{\circ} \mathrm{C}$ for $21 \mathrm{~min}$. Drops $(5 \mu \mathrm{l})$ of twofold serial dilutions of LDP solutions were deposited on each cap of whole sporophores, which were then incubated at $25^{\circ} \mathrm{C}$. For each toxin solution, three 5- $\mu$ l drops on three sporophores were used. Drops of sterile distilled water were used as control. The assays were performed at least twice.

\section{Haemolytic activity \\ of WLIP and the effect of osmoprotectants.}

Haemolytic activity of pure LDP was evaluated by an agarose plate assay and in solution on fresh heparinized RBC rinsed three times in a buffer $(30 \mathrm{mM}$ Tris- $\mathrm{HCl}, 100 \mathrm{mM} \mathrm{NaCl}, 1 \mathrm{mM}$ EDTA, pH 7).

Haemolytic activity of tolaasin I and WLIP on bovine RBC was evaluated on the agarose plate assay. Plates containing 10 $\mathrm{ml}$ of sterile agarose (1\% agarose in haemolysis buffer containing $20 \mathrm{mM}$ Tris- $\mathrm{HCl}, 0.85 \% \mathrm{NaCl}, \mathrm{pH}$ 7) and seeded with $\mathrm{RBC}$ suspensions, adjusted with the above buffer to give 0.2 absorbance values at $590 \mathrm{~nm}$, were used. Drops $(10-\mu \mathrm{l})$ of twofold serial dilutions of LDP solutions were deposited on the surface of plates that were then incubated at 25 and $37^{\circ} \mathrm{C}$ for $16 \mathrm{~h}$. The diameter of the clear zones was measured, and the haemolytic activity was expressed as M.H.Q. The experiment was repeated at least twice with three replicates.

Haemolytic activity of tolaasin I and WLIP on human RBC was determined by measuring the turbidity variation at $650 \mathrm{~nm}$ after the addition of LDP to RBC suspension. A 96-well microplate reader (UVmax, Molecular Devices, Sunnyvale, CA, U.S.A.) as described by Dalla Serra and associates (1999) was used. LDP solutions were serially diluted twofold from well to well with the above haemolysis buffer. The experiment started after supplementing each well with $100 \mu \mathrm{l}$ of RBC suspended in the haemolysis buffer (final volume $200 \mu \mathrm{l}$ per well). The apparent initial absorbance of intact RBC was about $100 \mathrm{mOD}$, which corresponded to $2.4 \times 10^{6}$ cells per well. The percentage of haemolysis was calculated as follows:

$$
\% \text { haemolysis }=100\left(\mathrm{~A}_{\mathrm{i}}-\mathrm{A}_{\mathrm{f}}\right) /\left(\mathrm{A}_{\mathrm{i}}-\mathrm{A}_{\mathrm{w}}\right)
$$

where $A_{i}$ and $A_{f}$ are the absorbance at the beginning and at the end of the experiment ( $4 \mathrm{~h}$ ) and $\mathrm{A}_{\mathrm{w}}$ the minimum value obtained after hypotonical lysis with pure water. All the experiments, performed at room temperature using flat bottom transparent microtiterplates, were repeated at least twice with three replicates.

Pore radius estimation was performed by using osmolite protectants with different hydrodynamic radii as described by Tejuca and associates (2001). A 30-mM final concentration of the following osmolites was added to the haemolysis buffer: sucrose (0.54), raffinose (0.66), stachiose (0.75) (from Acros Organics, Geel, Belgium), and polyethylene glycols 400 (0.56), 600 (0.69), 900 (0.85), 1,000 (0.92), 1,500 (1.2), 2,000 (1.4), 3,000 (1.7), and 4,000 (2.0) (from Fluka). The hydrodynamic radius of each osmolite in nm, taken from Schultz and Solomon (1961), Kuga (1981), and Carneiro et al. (1997), is reported in brackets after the compound names. The optical density data were analyzed by a theoretical model based on the Renkin equation (Renkin 1954) as described by Ginsburg and Stein (1987).

\section{ACKNOWLEDGMENTS}

The financial support of i) the "Progetto Giovani Ricercatori," biological characterization of the tolaasin and WLIP, lipodepsipeptides of P. to- laasii and $P$. reactans of the "Università degli Studi della Basilicata", ii) MURST ex 60\%, and iii) Istituto Trentino di Cultura and Provincia Autonoma di Trento (PAT, Project syrtox) are acknowledged. D. Sisto and N. Luisi (Università di Bari, Italy), A. Zoina (Università di Napoli "Federico II", Italy), and A. Logrieco (Istituto di Scienze delle Produzioni Alimentari, CNR, Bari, Italy) are also acknowledged for generously providing strains of fungi and chromista reported in Table 4.

\section{LITERATURE CITED}

Bassarello, C., Lazzaroni, S., Bifulco, G., Lo Cantore, P., Iacobellis, N. S. Riccio, R., Gomez-Paloma, L., and Evidente A. 2004. Tolaasins A-E, five new lipodepsipeptides produced by Pseudomonas tolaasii. Nat. Prod. 67:811-816.

Bender, C. L., Alarcón-Chaidez, F., and Gross, D. C. 1999. Pseudomonas syringae phytotoxins: Mode of action, regulation, and biosynthesis by peptide and polyketide synthetases. Microbiol. Mol. Biol. Rev. 63:266292.

Brodey, C. L., Rainy, P. B., Tester, M., and Johnstone, K. 1991. Bacterial blotch disease of the cultivated mushroom is caused by an ion channel forming lipodepsipeptide toxin. Mol. Plant-Microbe Interact. 4:407411.

Carneiro, C. M. M., Krasilnikov, O. V., Yuldasheva, L. N., de Carvalho, A. C. C., and Nogueira, R. A. 1997. Is the mammalian porin channel, VDAC, a perfect cylinder in the high conductance state? FEBS (Fed. Eur. Biochem. Soc.) Lett. 416:187-189.

Coraiola, I. M., Lo Cantore, P., Lazzaroni, S., Evidente, A., Iacobellis, N. S., and Dalla Serra, M. WLIP and tolaasin, lipodepsipeptides from Pseudomonas reactans and Pseudomonas tollaasii, permeabilise model membranes. BBA-Biomembranes. In press.

Dalla Serra, M., Fagiuoli, G., Nordera, P., Bernhart, I., Della Volpe, C., Di Giorgio, D., Ballio, A., and Menestrina, G. 1999. The interaction of lipodepsipeptide toxins from Pseudomonas syringae pv. syringae with biological and model membranes: A comparison of syringotoxin, syringomycin and syringopeptins. Mol. Plant-Microbe Interact. 12:391-400.

Ercolani, G. L. 1970. Primi risultati di osservazioni sulla maculatura batterica dei funghi coltivati [Agaricus bisporus (Lange) Imbach] in Italia Identificazione di Pseudomonas tolaasii Paine. Phytopath. Mediterr. 9:59-61

Ginsburg, H., and Stein, W. D. 1987. Biophysical analysis of novel transport pathways induced in red blood cell membranes. J. Membrane Biol. 96:1-10.

Godfrey, S. A. C., Marshall, J. W., and Klena, J. D. 2001. Genetic characterization of Pseudomonas "NZ17"-A novel pathogen that results in a brown blotch disease of Agaricus bisporus. J. Appl. Microbiol. 91:412420.

Goor, M., Vantomme, R., Swings, J., Gillis, M., Kersters, K., and De Ley, J. 1986. Phenotypic and genotypic diversity of Pseudomonas tolaasii and white line reacting organisms isolated from cultivated mushrooms. J. Gen. Microbiol. 132:2249-2264.

Han, F., Mortishire-Smith, R. J., Bainey, P. B., and Williams, D. H. 1992. The structure of the white line-inducing principle isolated from Pseudomonas "reactans." Acta Cryst. C-48: 1965-1968.

Hutchison, M. L., and Johnstone, K. 1993. Evidence for the involvement of the surface active properties of the extracellular toxin tolaasin in the manifestation of brown blotch disease symptoms by Pseudomonas tolaasii on Agaricus bisporus. Physiol. Mol. Plant Pathol. 42:373-384.

Iacobellis, N. S., and Lo Cantore, P. 1997. Bacterial diseases of cultivated mushrooms in southern Italy. Pages 33-37 in: Proceedings of 10th Congress of Mediterranean Phytopathological Union, Société Française de Phytopathologie (S.F.P.) (eds.). Bordeaux, France.

Iacobellis, N. S., and Lo Cantore, P. 1998a, Recenti acquisizioni sul determinismo della batteriosi del cardoncello (Pleurotus eryngii), Agricoltura Ricerca 176:51-54.

Iacobellis, N. S., and Lo Cantore, P. 1998b, Studi sull'eziologia dell'ingiallimento dell'ostricone (Pleurotus ostreatus), Agricoltura Ricerca 176:55-60.

Iacobellis, N. S., and Lo Cantore, P. 2003. Pseudomonas "reactans" a new pathogen of cultivated mushrooms. Pages 595-605 in: Pseudomonas syringae Pathovars and Related Pathogens. N. S. Iacobellis, A. Collmer, S. W. Hutcheson, J. W. Mansfield, C. E. Morris, J. Murillo, N. W. Schaad, D. E. Stead, G. Surico, and M. S. Ullrich, eds. Kluwer Academic Publishers, Dordrecht, The Netherlands. ISBN1-4020-1227-6.

Kim, J. W., Kwon, S. I., and Kang, H. J. 1995. Studies on the pathogenic Pseudomonas causing bacterial diseases of cultivated mushrooms in Korea. 2. Bacteriological characteristics of $P$. tolaasii causing mushroom brown blotch and white line reacting organisms. Korean J. Plant Pathol. 11:353-360.

King, E. O., Ward, M. K., and Raney, D. E. 1954. Two simple media for 
the demonstration of pyocyanin and fluorescein. J. Lab. Clin. Med. 44:301-307.

Kuga, S. 1981. Pore size distribution analysis of gel substances by size exclusion chromatography. J. Chromatog. 206:449-461.

Lavermicocca, P., Iacobellis, N. S., Simmaco, M., and Graniti, A. 1997. Biological properties and spectrum of activity of Pseudomonas syringae pv. syringae toxins. Physiol. Mol. Plant Pathol. 50:129-140.

Laycock, M. V., Hildebrand, P. D., Thibault, P., Walter, J. A., and Wright, J. L. C. 1991. Viscosin, a potent peptidolipid biosurfactant and phytopathogenic mediator produced by a pectolytic strain of Pseudomonas fluorescens. J. Agric. Food Chem. 39:483-489.

Lazzaroni, S., Bassarello, C., Bifulco, G., Lo Cantore, P., Evidente, A., Iacobellis N. S., Riccio, R., and Gomez-Paloma, L. 2003. Chemical and biological characterisation of tolaasins A-E: New lipodepsipeptides produced by Pseudomonas tolaasii. Pages 245-254 in: Pseudomonas syringae Pathovars and Related Pathogens. N. S. Iacobellis, ed. Kluwer Academic Publishers, Dordrecht, The Netherlands.

Lelliott R. A., and Stead D. E. 1987. Methods for the diagnosis of bacterial diseases of plants. Pages 216 in: Methods in Plant Pathology, Vol 2, T. F. Preece, ed. Blackwell Scientific Publications, Oxford, U.K.

Lo Cantore, P. 2001. Aspetti patogenetici, fisiologici e molecolari di Pseudomonas tolaasii e P. "reactans". Page 210 in: Tesi di Dottorato, Università degli Studi della Basilicata, Potenza, Italy.

Lo Cantore, P., and Iacobellis, N. S. 2002. Recenti acquisizioni sulla eziologia delle malattie batteriche dei funghi del genere Agaricus e Pleurotus. Micologia Italiana 2:18-27.

Lo Cantore, P., Lazzaroni, S., Evidente, A., Cafarchia, C., and Iacobellis N. S. 2003a. Production of Tolaasin I and WLIP by Pseudomonas tolaasii and P. "reactans", their Antimicrobial Activity and Possible Role in the Virulence of the Pathogens. Pages 255-262 in: Pseudomonas syringae Pathovars and Related Pathogens. N. S. Iacobellis, A. Collmer, S. W. Hutcheson, J. W. Mansfield, C. E. Morris, J. Murillo, N. W. Schaad, D. E. Stead, G. Surico, and M. S. Ullrich, eds. Kluwer Academic Publishers, Dordrecht, The Netherlands. ISBN1-4020-1227-6.

Lo Cantore, P., Coraiola, M., Dalla Serra, M., Menestrina, G., Lazzaroni, S., Evidente A., and Iacobellis, N. S. 2003b. Interaction of Tolaasin I and WLIP, Lipodepsipeptides of Pseudomonas tolaasii and P. "reactans", with biological and model membranes. Pages 263-273 in: Pseudomonas syringae Pathovars and Related Pathogens. N. S. Iacobellis, A. Collmer, S. W. Hutcheson, J. W. Mansfield, C. E. Morris, J. Murillo, N. W. Schaad, D. E. Stead, G. Surico, and M. S. Ullrich, eds. Kluwer Academic Publishers, Dordrecht, The Netherlands, ISBN: 1-4020-1227-6. ISBN1-4020-1227-6.

Menestrina, G., Coraiola, M., Fogliano, V., Fiore, A., Grgurina, I., Carpaneto, A., Gambale, F., and Dalla Serra, M. 2003. Antimicrobial lipodepsipeptides from Pseudomonas spp: A comparison of their activity on model membranes. Pages 185-198 in: Pseudomonas syringae Pathovars and Related Pathogens. N. S. Iacobellis, A. Collmer, S. W. Hutcheson, J. W. Mansfield, C. E. Morris, J. Murillo, N. W. Schaad, D. E. Stead, G. Surico, and M. S. Ullrich, eds. Kluwer Academic Publishers, Dordrecht, The Netherlands. ISBN1-4020-1227-6.

Mortishire-Smith, R. J., Nutkins, J. C., Packman, L. C., Brodey, C. L., Rainey, P. B., Johnstone, K., and Williams, D. H. 1991. Determination of the structure of an extracellular peptide produced by the mushroom saprotroph Pseudomonas "reactans." Tetrahedron 47:3645-3654.

Munsch, P., and Alatossava T. 2002a. The white-line-in-agar test is not specific for the two cultivated mushroom associated pseudomonads, Pseudomonas tolaasii and Pseudomonas "reactans." Microbiol. Res. 157:7-11.
Munsch, P., and Alatossava, T. 2002b. Several pseudomonads, associated with the cultivated mushrooms Agaricus bisporus or Pleurotus sp., are haemolytic. Microbiol. Res. 157:311-315.

Munsch, P., Geoffroy, V., Alatossava, T., and Meyer, J. M. 2000. Application of siderotyping for characterization of Pseudomonas tolaasii and "Pseudomonas reactans" isolates associated with brownblotch disease of cultivated mushrooms. Appl. Environ. Microbiol. 66:4834-4841.

Munsch, P., Alatossava, T., Martinnen, N., Meyer, J. M., Christen, R., and Gardan, L. 2002. Pseudomonas costantinii sp. nov., another causal agent of brown blotch disease, isolated from cultivated mushroom sporophores in Finland. Int. J. Syst. Evol. Microbiol. 52:1973-1983.

Neu, T. R., Härtner, T., and Poralla, K. 1990. Surface active properties of viscosin: A peptidolipid antibiotic. Appl. Microbiol. Biotech. 32:518520.

Nutkins, J. C., Mortishire-Smith, R. J., Packman, L. C., Brodey, C. L., Rainey, P. B., Johnstone, K., and William, D. H. 1991. Structure determination of tolaasin, an extracellular lipodepsipeptide produced by the mushroom pathogen Pseudomonas tolaasii Paine. J. Am. Chem. Soc. 113:2621-2627.

Paine, S. G. 1919. Studies in bacteriosis II. A brown blotch disease of cultivated mushroom. Ann. Appl. Biol. 5:206-219.

Peng, J. T. 1986. Resistance to disease in Agaricus bisporus (Lange) Imbach. Ph.D. thesis. University of Leeds, Department of Plant Science, U.K.

Rainey, P. B., Brodey, C. L., and Johnstone, K. 1991. Biological properties and spectrum of activity of tolaasin, a lipodepsipeptide toxin produced by the mushroom pathogen Pseudomonas tolaasii. Physiol. Mol. Plant Pathol. 39:57-70.

Rainey, P. B., Brodey, C. L., and Johnstone, K. 1992. Biology of Pseudomonas tolaasii, cause of brown blotch disease of the cultivated mushroom. Plant Pathol. 8:95-117.

Renkin, E. M. 1954. Filtration, diffusion, and molecular sieving through porous cellulose membranes. J. Gen. Physiol. 38:225-243.

Schultz, S. G., and Solomon, A. K. 1961. Determination of the effective hydrodynamic radii of small molecules by viscometry. J. Gen. Physiol. 44:1189-1199.

Shirata, A., Sugaya, K., Takasugi, M., and Monde, K. 1995. Isolation and biological activity of toxins produced by a Japanese strain of Pseudomonas tolaasii, the pathogen of bacterial rot of cultivated oyster mushroom. Ann. Phytopathol Soc. Jpn. 61:493-502.

Sinden, S. L., De Vay, J. E., and Backman, P. A. 1971. Properties of syringomicin, a wide spectrum antibiotic and phytotoxin produced by $\mathrm{Pseu}$ domonas syringae, and its role in the bacterial canker disease of peach trees. Physiol. Plant Pathol. 1:199-213.

Soler-Rivas, C., Jolivet S., Arpin, N., Olivier, J. M., and Wichers, H. J. 1999. Biochemical and physiological aspects of brown blotch disease of Agaricus bisporus. FEMS (Fed. Eur. Microbiol. Soc.) Microbiol. Rev. 23:591-614.

Tejuca, M., Dalla Serra, M., Alvarez, C., Potrich, C., and Menestrina, G. 2001. Sizing the radius of the pore formed in erythrocytes and lipid vesicles by the toxin sticholysin I from the sea anemone Stichodactyla helianthus. J. Membrane Biol. 183:125-135.

Wells, J. M., Sapers, G. M., Fett, W. F., Butterfield, J. E., Jones, J. B., Bouzar, H., and Miller, F. C. 1996. Postharvest discoloration of the cultivated mushrooms Agaricus bisporus caused by Pseudomonas tolaasii, $P$. "reactans", and P. "gingeri". Phytopathology 86:1098-1104.

Wong, W. C., and Preece, T. F. 1979. Identification of Pseudomonas tolaasii: The white line in agar and mushroom tissue block rapid pitting tests. J. Appl. Bacteriol. 47:401-407. 